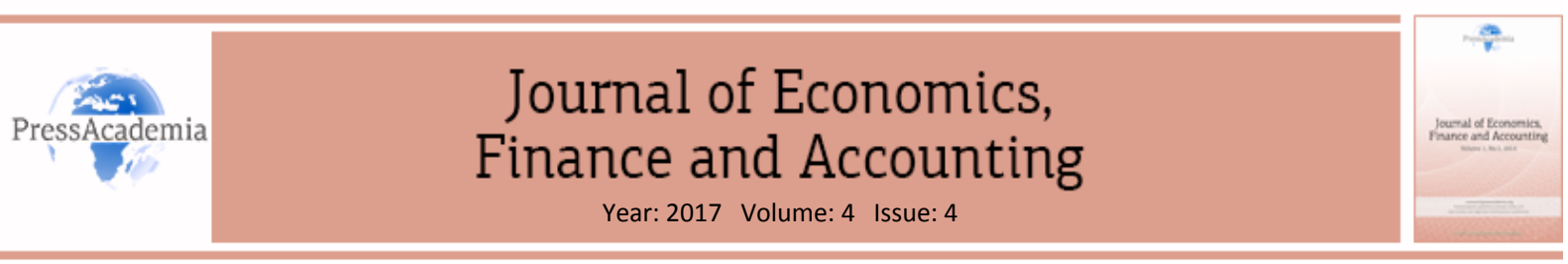

\title{
ANALYZING MOBILE BANKING QUALITY FACTORS UNDER NEUTROSOPHIC SET PERSPECTIVE: A CASE STUDY OF TURKEY
}

\author{
DOI: 10.17261/Pressacademia.2017.746 \\ JEFA- V.4-ISS.4-2017(1)-p.354-367
}

\author{
Serpil Altinirmak ${ }^{1}$, Basil Okoth ${ }^{2}$, Mustafa Ergun ${ }^{3}$ Caglar Karamasa $^{4}$ \\ ${ }^{1}$ Anadolu University,Department of Finance, Eskişehir, Turkey. saltinirmak@anadolu.edu.t r \\ ${ }^{2}$ Anadolu University, Department of Business Administration, Eskişehir, Turkey. Basils.okoth@yahoo.com \\ ${ }^{3}$ Anadolu University,Department of Geographic Information Systems, Eskişehir, Turkey. mustafaergun@gmail.com \\ ${ }^{4}$ Anadolu University, Department of Quantitative Methods, Eskişehir Turkey. ckaramasa@hotmail.com
}

To cite this document

Altinirmak, S., Okoth, B., Ergun, M., Karamasa, C. (2017). Analysing mobile banking quality factors from neutrosophic set perspective: a case of study of Turkey, Journal of Economics, Finance and Accounting (JEFA), V.4, Iss.3, p.354-367.

Permanent link to this document: http://doi.org/10.17261/Pressacademia.2017.746

Copyright: Published by PressAcademia and limited licenced re-use rights only.

\begin{abstract}
Purpose - Mobile banking, also known as m-banking, provides low cost, innovative and easily accessible services to customers with technological developments as compared to retail banking. In this context, m-banking quality factors of the banks are considered to be important issues for customers. The aim of this study is to analyze the $\mathrm{m}$-banking quality factors and to rank banks offering this service in Turkey under incomplete, inconsistent and indeterminate information.

Methodology - First linguistic expressions of experts are converted to crisp values via approximation approach proposed by Chen and Hwang. Then, the Single Valued Neutrosophic Set (SVNS) based entropy, which deals with incomplete, indeterminate and inconsistent environment better than fuzzy set, is used to rank the banks providing $\mathrm{m}$-banking services in Turkey.

Findings- Findings show that the Denizbank has the best performance in m-banking applications followed by TEB and ING. Additionally, in terms of entropy weights, response time was found to be the most important criterion followed by accessibility, accuracy and trust.

Conclusion- Banks could consider the criteria of response time, accessibility, accuracy and trust for improving the performance in mbanking services implementation.
\end{abstract}

Keywords: Mobile banking, quality factors, neutrosophic set, single valued neutrosophic set based entropy.

JEL Codes: C44, G21, 032

\section{INTRODUCTION}

Within the last decade, banks started to provide innovative products and offer low-cost services via various distribution channels as a result of increased competition in the financial service sector. Technological developments can be considered as a crucial point for financial services industry. Since the 1990s it is possible to offer low cost, convenient, easily accessible and high value-added services in the banking sector as a pioneer in adopting internet and mobile technology (Laukkanen, 2007: 788-797).Alternative distribution channels provide cross-selling and new opportunities in terms of selling diversified services for banks. Another advantage of alternative distribution channels is the mitigation of fixed costs resulting from branches' physical maintenance, marketing and labor force costs.

Services that are offered to customers via mobile banking, also known as $m$-banking, include authentication, user friendly interfaces, contactless payment systems, dynamic credit opportunities, fund transfers, offering innovative products to customers at point of sales, $24 / 7$ tracing of sales transactions and giving warnings to customers, bill payments via mobile phones, real-time access to bank statement and debt accounts, invoice payment, anytime and anywhere connectivity to banking services (Derbent, 2011: 164-171).It can be stated that the most significant barrier to the adoption of $m$-banking are the security concerns. Additionally, other essential factors may include individuals' past experiences with information and technology, and the lack of awareness of the benefits of $m$-banking (Laforet and Li, 2005:362-380).

Banking is one of the leading sectors with respect to technological investment in Turkey as around the world. The number of customers using mobile banking services in Turkey within the period between September 2015 and September 2016 can 
be seen in Table 1 below. According to the Table 1, the total number of registered customers that logged in at least once for the purpose of mobile banking in September 2016 was about 27.5 million. Compared to September 2015, this number increased by $64 \%$. Additionally, the total number of registered customers that logged in at least once in 1-year period for mobile banking in September 2016 was about 21.5 million. Again, compared to September 2015 this number increased by $\% 57$ (https://www.tbb.org.tr/en/banks-and-banking-sector-information/statistical-reports/20).

The total number of registered customers that logged in at least once for mobile banking in June 2017 was about 37.5 million. Also, 24.5 million registered customers logged in at least once within the period of April-June 2017. The total number of active customers (retail and commercial) increased by about 2 million compared to the previous year. Lastly, the total number of registered customers that logged in at least once in 1 year period for mobile banking in June 2017 was about 30.5 million (https://www.tbb.org.tr/tr/internet and mobile banking statistics/3635).

Table 1: Number of Customers Using Mobile Banking Services

\begin{tabular}{|c|c|c|}
\hline Period & $\begin{array}{r}\text { September } \\
2015 \\
\end{array}$ & $\begin{array}{r}\text { September } \\
2016 \\
\end{array}$ \\
\hline \multicolumn{3}{|l|}{ Retail } \\
\hline $\begin{array}{l}\text { Total number of registered customers that logged in at least } \\
\text { once }\end{array}$ & 16.078 .726 & 26.368 .898 \\
\hline $\begin{array}{l}\text { Total number of registered customers that logged in at least } \\
\text { once in 1-year period }\end{array}$ & 13.104 .657 & 20.587 .036 \\
\hline Number of active customers & 10.078 .480 & 16.105 .995 \\
\hline \multicolumn{3}{|l|}{ Commercial } \\
\hline $\begin{array}{l}\text { Total number of registered customers that logged in at least } \\
\text { once }\end{array}$ & 549.833 & 889.139 \\
\hline $\begin{array}{l}\text { Total number of registered customers that logged in at least } \\
\text { once in 1-year period }\end{array}$ & 471.586 & 675.706 \\
\hline Number of active customers & 356.046 & 507.234 \\
\hline \multicolumn{3}{|l|}{ Total } \\
\hline $\begin{array}{l}\text { Total number of registered customers that logged in at least } \\
\text { once }\end{array}$ & 16.628 .559 & 27.258 .037 \\
\hline $\begin{array}{l}\text { Total number of registered customers that logged in at least } \\
\text { once in } 1 \text { year period }\end{array}$ & 13.576 .243 & 21.262 .742 \\
\hline Number of active customers & 10.434 .526 & 16.613 .229 \\
\hline
\end{tabular}

While the total number of financial transactions via m-banking within the period of January-March 2016 was about 102 million, the total amount transacted was 190 billion Turkish lira. Money transfers involving EFT, money orders and foreign currency transfers constitute $59 \%$ of financial transactions volume (https://www.tbb.org.tr/tr/internet and mobile banking statistics/3635). From the forgoing, it is essential to analyze the rapidly growing Turkish mobile banking system in terms of its quality factors.

Lin (2013) defines the concept of $m$-banking quality as customer judgments with respect to the quality of mobile content delivery in terms of $m$-banking. Mobile banking quality factors can therefore be considered as important issues for customers.

In this study, we seek to evaluate the satisfaction levels of users of $m$-banking applications of thirteen banks operating in Turkey. For this purpose, sixteen mobile banking quality criteria are examined and banks providing these services are ranked under the single valued neutrosophic sets (SVNS) entropy based multi-attribute decision making (MADM).

This study is organized in five sections. Brief introduction of the $\mathrm{m}$-banking concept is explained in section 1 . M-banking related literature review is presented in section 2 . The data and methodology of study are introduced in section 3 . Findings and discussions are given in section 4. Finally concluding remarks are mentioned in section 5.

\section{LITERATURE REVIEW}

Tan and Chou (2008) analyzed the effects of mobile service quality and its compatibility with mobile technology on users' perceived playfulness in terms of mobile information and entertainment services. To achieve this, partial least squares (PLS) technique was used by considering seven mobile service quality dimensions namely perceived usefulness, perceived ease of use, content, variety, feedback, experimentation and personalization. According to the results of PLS, perceived usefulness, perceived ease of use and personalization were found to be crucial mobile service quality factors that had an impact on perceived playfulness. In addition to that, mobile service quality and perceived technology compatibility as a mediator, significantly affected the users' perceived playfulness. 
Kim, Shin and Lee (2009) examined the mechanisms related to the initial formation of people's trust in mobile banking and intention to use the service via structural equation modeling. For this purpose, four antecedent variables namely structural assurances, trust propensity, firm reputation and relative benefits were considered to be responsible for shaping a person's initial trust in mobile banking and its usage intention. The results concluded that three variables (the exception being firm's reputation) significantly affected people's initial trust in mobile banking and its usage intention as well.

Lu, Zhang and Wang (2009) studied a multidimensional and hierarchical model of mobile service quality in terms of mobile brokerage service. Sample from the two largest mobile service providers in China was analyzed in interaction, environment and outcome dimensions of mobile service quality. They found that the corporate image had significant moderating effects on the impacts of the environment and outcome qualities on mobile brokerage service quality.

Yu and Fang (2009) proposed a measurement model for post-adoption user perception of mobile banking services by using exploratory and confirmatory factor analyses. Additionally, the index for customer post-adoption perception was calculated using factor loadings. Six factors (security service, interactivity, relative advantage, ease of use, interface creativity and customer satisfaction) were found to be reliable, valid and useful for this purpose.

Zhuo and Li (2010) assessed the mobile banking services of the eight major Chinese banks by constructing an evaluation model composed of five main criteria; system quality, information quality, interface design quality, brand quality and fees and privilege. The analytic hierarchy process was used for weighting criteria and ranking of the banks. While system quality was considered as highly important criterion, interface design quality was ranked as the lowest measure.

Zhou (2012) evaluated the users' initial trust in mobile banking by using elaboration likelihood model (ELM) with regards to central (information and service quality) and peripheral (system quality, reputation and structural assurance) cues. According to the results of the ELM, both central and peripheral cues had a significant impact on initial trust. Information quality, system quality and structural assurance had a larger impact on users' initial trust in mobile banking compared to the other factors. Also, self-efficacy positively moderated the effects of central cues composed of information and service quality on users' initial trust in mobile banking. On the contrary, it negatively moderated the effects of peripheral cues composed of system quality and structural assurance on users' initial trust in mobile banking.

Lin (2013) evaluated the relative importance of mobile banking quality factors between low (using mobile banking a few times a month or less) and high (using mobile banking a few times a week or more) experience groups via fuzzy analytic hierarchy process. Both groups were found to regard customer service as an important mobile banking quality factor.

Padmanaban and Joseph (2014) analyzed the factors that had an impact on customers' adoption of mobile banking services in Chennai city via factor analysis. As a result, four significant factors composed of twelve items (banking hours, costeffectiveness, convenience, fund transfers, credibility, brand image, viewing transaction history, accessibility, mobility, standard of living, convenient shopping and utility bill payment) were found to influence the customers' adoption of mobile banking services.

As can be seen in the literature, there are various viewpoints with respect to mobile banking quality factors. In this study, having sufficient construct validity and reliability, proposed by Lin (2013) are adopted as the measurement criteria. Accordingly, sixteen mobile banking quality criteria (accessibility, response time, mobility, security, accuracy, currency, relevance, completeness, reliability, responsiveness, trust, empathy, multimedia capability, format, understandability and navigability) are considered as explained in Table 2.

Table 2: Descriptions of Mobile Banking Quality Criteria

\begin{tabular}{|ll|}
\hline Mobile Banking Quality Criteria & Description \\
\hline Accessibility (C1) & Easy to access for conducting banking transactions \\
\hline Response time (C2) & Reasonable waiting time for loading banking transactions \\
\hline Mobility (C3) & $\begin{array}{l}\text { It's possible to access mobile banking at any time and } \\
\text { anywhere }\end{array}$ \\
\hline Security (C4) & $\begin{array}{l}\text { Mobile banking provides enough security for banking } \\
\text { transactions }\end{array}$ \\
\hline Accuracy (C5) & Mobile banking provides accurate information \\
\hline Currency (C6) & \begin{tabular}{l} 
Mobile banking provides current information \\
\hline Relevance (C7)
\end{tabular} \\
\hline Completeness (C8) & $\begin{array}{l}\text { Relevant information associated with banking transactions } \\
\text { is provided through mobile banking }\end{array}$ \\
\hline Reliability (C9) & $\begin{array}{l}\text { Customers can use a complete set of information via } \\
\text { mobile banking }\end{array}$ \\
\hline
\end{tabular}




\begin{tabular}{|ll|}
\hline Responsiveness (C10) & $\begin{array}{l}\text { Mobile banking applications show responsiveness toward } \\
\text { customer inquiries }\end{array}$ \\
\hline Trust (C11) & $\begin{array}{l}\text { Usage of mobile devices in banking transactions provides } \\
\text { confidence }\end{array}$ \\
\hline Empathy (C12) & $\begin{array}{l}\text { Individual attention is provided to customers based on their } \\
\text { transaction history via mobile banking }\end{array}$ \\
\hline Multimedia capability (C13) & $\begin{array}{l}\text { Suitable multimedia (e.g. graphic, image) presentation is } \\
\text { provided to customers through mobile banking }\end{array}$ \\
\hline Format (C14) & $\begin{array}{l}\text { Contents of mobile banking transactions (e.g. range, depth, } \\
\text { structure) are clearly presented }\end{array}$ \\
\hline Understandability (C15) & $\begin{array}{l}\text { It is easy to understand mobile banking presentations } \\
\text { Navigability (C16) }\end{array}$ \\
$\begin{array}{l}\text { It is easy to find information through navigation provided } \\
\text { by mobile banking }\end{array}$ \\
\hline
\end{tabular}

Source: Lin (2013), p.198.

\section{DATA AND METHODOLOGY}

Data was collected by designing and applying survey between dates September 10, 2017 and October 15, 2017. Descriptive analysis of the survey is presented in Table 3.

Table 3: Descriptive Analysis of the Study

\begin{tabular}{|c|c|c|c|}
\hline \multicolumn{2}{|c|}{ Demographic Variables } & \multirow{2}{*}{$\begin{array}{c}\text { Frequency } \\
16\end{array}$} & \multirow{2}{*}{$\begin{array}{c}\text { Percent (\%) } \\
45.71\end{array}$} \\
\hline Gender & Female & & \\
\hline & Male & 19 & 54.29 \\
\hline \multirow[t]{4}{*}{ Age } & $18-30$ & 7 & 20 \\
\hline & $31-40$ & 12 & 34.28 \\
\hline & $41-50$ & 9 & 25.72 \\
\hline & $51-60$ & 7 & 20 \\
\hline \multirow{4}{*}{$\begin{array}{l}\text { Mobile banking } \\
\text { monthly usage } \\
\text { frequency }\end{array}$} & $1-3$ & 10 & 28.57 \\
\hline & $4-6$ & 8 & 22.86 \\
\hline & $7-9$ & 10 & 28.57 \\
\hline & Over 10 & 7 & 20 \\
\hline \multirow[t]{3}{*}{ Education } & Bachelor's degree & 23 & 65.71 \\
\hline & Post-graduate & 4 & 11.43 \\
\hline & Doctorate & 8 & 22.86 \\
\hline \multirow[t]{3}{*}{ Institution } & University (academicians) & 8 & 22.86 \\
\hline & Public sector & 10 & 28.57 \\
\hline & Private Sector & 17 & 48.57 \\
\hline
\end{tabular}


Sixteen mobile banking quality criteria and thirteen banks (Ziraat Bankasi, Halk Bankasi, Vakiflar Bankasi, Akbank, Garanti Bankasi, İs Bankasi, Yapi ve Kredi Bankasi, Finansbank, TEB, Denizbank, ING, Sekerbank and HSBC) providing mobile banking services are included in survey and named as A1 to A13.

\subsection{Converting Linguistic Terms to Crisp Scores}

Most of the real-world MADM problems can contain fuzzy data apart from crisp ones. Therefore, a number of fuzzy MADM methods are proposed to solve these types of problems. But most of them require computational complexity when considered in detail. This caused drawbacks in solving real-world problems with with more than ten attributes relating to more than 10 alternatives (Rao, 2007, p.43).

Chen and Hwang (1992) presented a two-stage numerical approximation approach in order to overcome these disadvantages in a fuzzy environment. In the first stage, linguistic terms are systematically converted into fuzzy numbers and then the fuzzy numbers into crisp scores. A decision matrix composed of criteria and alternatives in crisp form is obtained as the result of the first stage. Then a suitable MADM method is applied for the ranking of determined alternatives. The method uses a fuzzy scoring approach for converting fuzzy numbers into crisp scores. The crisp score of fuzzy number F can be found according to Eq. (1) and (2) (Rao, 2007, p.44; Rao \& Parnichkun, 2009, pp.6996-6997):

$$
\begin{aligned}
& \mu_{\max }(x)= \begin{cases}x, & 0 \leq x \leq 1 \\
0, & \text { otherwise }\end{cases} \\
& \mu_{\text {min }}(x)= \begin{cases}1-x, & 0 \leq x \leq 1 \\
0, & \text { otherwise }\end{cases}
\end{aligned}
$$

The fuzzy max and fuzzy min of fuzzy numbers which are described can be included in comparison cases. The left score $\left(\mu_{L}\left(F_{i}\right)\right)$ of each fuzzy number $\left(F_{i}\right)$ is determined according to Eq. (3):

$$
\mu_{L}\left(F_{i}\right)=\sup _{x}\left[\mu_{\min }(x) \wedge \mu_{F i}(x)\right]
$$

The $\mu_{L}\left(F_{i}\right)$ score which lies in $(0,1)$ is the maximum membership value of the intersection of the fuzzy number $\left(F_{i}\right)$ and fuzzy min. Similarly, the right score $\left(\mu_{R}\left(F_{i}\right)\right)$ of each fuzzy number $\left(F_{i}\right)$ can be obtained as Eq. (4):

$$
\mu_{R}\left(F_{i}\right)=\sup _{x}\left[\mu_{\max }(x) \wedge \mu_{F i}(x)\right]
$$

The $\mu_{R}\left(F_{i}\right)$ score which lies in $[0,1]$ is the maximum membership value of the intersection of the fuzzy number $\left(F_{i}\right)$ and fuzzy max. In addition to these, the total score $\left(\mu_{T}\left(F_{i}\right)\right)$ of a fuzzy number $\left(F_{i}\right)$ is determined as Eq. (5):

$$
\mu_{T}\left(F_{i}\right)=\left[\mu_{R}\left(F_{i}\right)+1-\mu_{L}\left(F_{i}\right)\right] / 2
$$

A 5-point scale having linguistic terms 'low, below average, average, above average and high' is used to show the conversion of fuzzy numbers into crisp scores as shown in Table 4.

Table 4: A Five-Point Scale Developed for the Conversion of Fuzzy Numbers into Crisp Scores

\begin{tabular}{|ll|}
\hline $\begin{array}{l}\text { Linguistic } \\
\text { Terms }\end{array}$ & $\begin{array}{l}\text { Fuzzy } \\
\text { Number }\end{array}$ \\
\hline Low & $F_{1}$ \\
\hline Below average & $F_{2}$ \\
\hline Average & $F_{3}$ \\
\hline Above average & $F_{4}$ \\
\hline High & $F_{5}$ \\
\hline
\end{tabular}

Additionally, the membership of these fuzzy numbers $\left(\mathrm{F}_{1}, \mathrm{~F}_{2}, \mathrm{~F}_{3}, \mathrm{~F}_{4}, \mathrm{~F}_{5}\right)$ are calculated by considering Eqs. (6) -(10) as follows: 


$$
\begin{gathered}
\mu_{F 1}(x)= \begin{cases}1, \quad x=0 \\
(0.3-x) /(0.3), & 0 \leq x \leq 0.3\end{cases} \\
\mu_{F 2}(x)= \begin{cases}(x-0) /(0.25), & 0 \leq x \leq 0.3 \\
(0.5-x) /(0.25), & 0.25 \leq x \leq 0.5\end{cases} \\
\mu_{F 3}(x)= \begin{cases}(x-0.3) /(0.2) & 0.3 \leq x \leq 0.5 \\
(0.7-x) /(0.2), & 0.5 \leq x \leq 0.7\end{cases} \\
\mu_{F 4}(x)= \begin{cases}(x-0.5),(0.25) & 0.5 \leq x \leq 0.75 \\
(1-x) /(0.25), & 0.75 \leq x \leq 1\end{cases} \\
\mu_{F 5}(x)= \begin{cases}(x-0.7),(0.3) & 0.7 \leq x \leq 1 \\
1, & x=1\end{cases}
\end{gathered}
$$

The left, right and the total scores for the fuzzy number $\left(F_{1}\right)$ can be computed by considering Eqs. (11) - (13) as follows:

$$
\begin{gathered}
\mu_{L}\left(F_{1}\right)=\sup _{x}\left[\mu_{\text {min }}(x) \wedge \mu_{F 1}(x)\right]=1 \\
\mu_{R}\left(F_{1}\right)=\sup _{x}\left[\mu_{\text {max }}(x) \wedge \mu_{F 1}(x)\right]=0.23 \\
\mu_{T}\left(F_{1}\right)=\left[\mu_{R}\left(F_{1}\right)+1-\mu_{L}\left(F_{1}\right)\right] / 2=0.115
\end{gathered}
$$

The left, right and the total scores for other fuzzy numbers $\left(F_{2}, F_{3}, F_{4}, F_{5}\right)$ are calculated in a similar manner and shown as Table 5:

Table 5: Left, Right and Total Scores for Fuzzy Numbers (5-point scale)

\begin{tabular}{|lccc|}
\hline Fuzzy Number & Left score $\left(\mu_{L}\left(F_{i}\right)\right)$ & Right score $\left(\mu_{R}\left(F_{i}\right)\right)$ & Total score $\left(\mu_{T}\left(F_{i}\right)\right)$ \\
\hline$F_{1}$ & 1 & 0.23 & 0.115 \\
\hline$F_{2}$ & 0.8 & 0.39 & 0.295 \\
\hline$F_{3}$ & 0.59 & 0.58 & 0.495 \\
\hline$F_{4}$ & 0.4 & 0.79 & 0.695 \\
\hline$F_{5}$ & 0.23 & 1 & 0.895 \\
\hline
\end{tabular}

Thus, linguistic terms with their crisp scores can be represented as in Table 6:

Table 6: Conversion of Linguistic Terms into Crisp Scores (5-point scale)

\begin{tabular}{|lcc|}
\hline Linguistic Terms & Fuzzy Number & Crisp Score \\
\hline Low & $F_{1}$ & 0.115 \\
\hline Below average & $F_{2}$ & 0.295 \\
\hline Average & $F_{3}$ & 0.495 \\
\hline Above average & $F_{4}$ & 0.695 \\
\hline High & $F_{5}$ & 0.895 \\
\hline
\end{tabular}


Any scale (5-point scale, 8-point scale, 9-point scale or 11-point scale) can be applied and corresponding values assigned to qualitative attributes. In this study, an 11-point scale shown in Table 7 is considered for detailed representation of the value of qualitative attributes such as mobile banking quality factors.

Table 7: Conversion of Linguistic Terms into Crisp Scores (11-point scale) in Terms of Mobile Banking Quality Factors

\begin{tabular}{|lcc|}
\hline Linguistic Terms & Fuzzy Number & Crisp Score \\
\hline Exceptionally low & $F_{1}$ & 0.045 \\
\hline Extremely low & $F_{2}$ & 0.135 \\
\hline Very low & $F_{3}$ & 0.255 \\
\hline Low & $F_{4}$ & 0.335 \\
\hline Below average & $F_{5}$ & 0.410 \\
\hline Average & $F_{6}$ & 0.500 \\
\hline Above average & $F_{7}$ & 0.590 \\
\hline High & $F_{8}$ & 0.665 \\
\hline Very high & $F_{9}$ & 0.745 \\
\hline Extremely high & $F_{10}$ & 0.865 \\
\hline Exceptionally high & $F_{11}$ & 0.955 \\
\hline
\end{tabular}

\subsection{Neutrosophic Set}

Smarandache (1998) introduced the concept of Neutrosophic Sets (NS) with a degree of truth, indeterminacy and falsity membership functions, in which all of them are totally independent. Let $U$ be a universe of discourse and $x \in U$. The neutrosophic set (NS) $\mathrm{N}$ can be expressed by a truth membership function $T_{N}(x)$, an indeterminacy membership function $I_{N}(x)$ and a falsity membership function $F_{N}(x)$, and is represented as $N=\left\{<x: T_{N}(x), I_{N}(x), F_{N}(x)>, x \in U\right\}$. Also, the functions of $T_{N}(x), I_{N}(x)$ and $F_{N}(x)$ are real standard or real non-standard subsets of $\rho^{-}, 1^{+}\lfloor$and can be presented as $T, I, F: U \rightarrow\rfloor \rho^{-}, 1^{+}\lfloor$. There is no restriction on the sum of the functions of $T_{N}(x), I_{N}(x)$ and $F_{N}(x)$, so this can be represented as Eq. (14):

$$
0^{-} \leq \sup T_{N}(x)+\sup I_{N}(x)+\sup F_{N}(x) \leq 3^{+}
$$

The complement of an NS N is represented by $N^{C}$ and described as Eqs. (15) - (17):

$$
\begin{aligned}
& T_{N}^{C}(x)=1^{+} \ominus T_{N}(x) \\
& I_{N}^{C}(x)=1^{+} \ominus I_{N}(x) \\
& \qquad F_{N}^{C}(x)=1^{+} \ominus F_{N}(x) \text { for all } x \in U
\end{aligned}
$$

An NS N is contained in other NS $\mathrm{P}$, in other words, $N \subseteq P$ if and only if inf $T_{N}(x) \leq \inf T_{P}(x)$, $\sup T_{N}(x) \leq \sup T_{P}(x), \inf I_{N}(x) \geq \inf I_{P}(x), \sup I_{N}(x) \geq \sup I_{P}(x), \inf F_{N}(x) \geq \inf F_{P}(x)$, $\sup F_{N}(x) \geq \sup F_{P}(x)$ for all $x \in U$ (Biswas, Pramanik \& Giri, 2016b, pp.728-729). 


\subsection{Single-Valued Neutrosophic Sets (SVNS)}

Wang, Smarandache, Zhang and Sunderraman (2010) developed the term of Single Valued Neutrosophic Set (SVNS) which is a case of NS, in order to deal with indeterminate, inconsistent and incomplete information. They handle the interval $[0,1]$ instead of $0^{-}, 1^{+}$to better apply to real-world problems. Let $\mathrm{U}$ be a universe of discourse and $x \in U$. A singlevalued neutrosophic set $\mathrm{B}$ in $\mathrm{U}$ is described by a truth membership function $T_{B}(x)$, an indeterminacy membership function $I_{B}(x)$ and a falsity membership function $F_{B}(x)$. When $\mathrm{U}$ is continuous an SVNS B is depicted as $B=\int_{x} \frac{<T_{B}(x), I_{B}(x), F_{B}(x)>}{x}: x \in U$. When $\mathrm{U}$ is discrete an sVNS $\mathrm{B}$ can be represented as $B=\sum_{i=1}^{n} \frac{<T_{B}\left(x_{i}\right), I_{B}\left(x_{i}\right), F_{B}\left(x_{i}\right)}{x_{i}}: x_{i} \in U$ (Mondal, Pramanik \& Smarandache, 2016, p.95). The functions of $T_{B}(x), I_{B}(x)$ and $F_{B}(x)$ are real standard subsets of $[0,1]$ that is $T_{B}(x): U \rightarrow[0,1], I_{B}(x): U \rightarrow[0,1]$ and $F_{B}(x): U \rightarrow[0,1]$. Also, the sum of $T_{B}(x), I_{B}(x)$ and $F_{B}(x)$ are in $[0,3]$ that $0 \leq T_{B}(x)+I_{B}(x)+F_{B}(x) \leq 3$ (Biswas, Pramanik \& Giri, 2016a, p.29).

For simplicity two SVNSs such as $B_{1}=\left(t_{1}, l_{1}, f_{1}\right)$ and $B_{2}=\left(t_{2}, l_{2}, f_{2}\right)$ then summation between $B_{1}$ and $B_{2}$ can be described as Eq.(18) (Şahin \& Yiğider, p.3):

$$
B_{1} \oplus B_{2}=\left(t_{1}+t_{2}-t_{1} t_{2}, l_{1} l_{2}, f_{1} f_{2}\right)
$$

Two SVNSs such as $B_{1}=\left(t_{1}, l_{1}, f_{1}\right)$ and $B_{2}=\left(t_{2}, l_{2}, f_{2}\right)$ then multiplication between $B_{1}$ and $B_{2}$ can be described as Eq. (19):

$$
B_{1} \otimes B_{2}=\left(t_{1} t_{2}, l_{1}+l_{2}-l_{1} l_{2}, f_{1}+f_{2}-f_{1} f_{2}\right)
$$

For an SVNS as $B=(t, l, f)$ and $\lambda \in \mathfrak{R}$ an arbitrary positive real number and shown as Eq. (20),

$$
\lambda B=\left(1-(1-t)^{\lambda}, l^{\lambda}, f^{\lambda}\right), \lambda>0 .
$$

For two SVNSs such as $B_{1}=\left(t_{1}, l_{1}, f_{1}\right)$ and $B_{2}=\left(t_{2}, l_{2}, f_{2}\right)$, the conditions namely $B_{1} \subseteq B_{2}$ and $B_{1}=B_{2}$ are identified as Eqs. (21)-(22) (Mondal, Pramanik \& Smarandache, 2016, p.95):

$$
\begin{aligned}
& B_{1} \subseteq B_{2} \text { if and only if } t_{1} \leq t_{2}, l_{1} \geq l_{2}, f_{1} \geq f_{2} \\
& B_{1}=B_{2} \text { if and only if } t_{1}=t_{2}, l_{1}=l_{2}, f_{1}=f_{2}
\end{aligned}
$$

The complement of a SVNS B is represented by ${ }_{C}(B)$ and is described as Eqs. (23) - (25) (Hussain, Mohamed, Abdel-Baset \& Smarandache, 2017, p.17):

$$
\begin{gathered}
T_{C}(B)(x)=F(B)(x) \\
I_{C}(B)(x)=1-I(B)(x) \\
F_{C}(B)(x)=T(B)(x) \text { for all } x \in U
\end{gathered}
$$

The union of two SVNS namely $B_{1}$ and $B_{2}$ is an SVNS $B_{3}$ denoted by $B_{3}=B_{1} \cup B_{2}$ and its truth, indeterminacy and falsity membership functions are shown as Eqs. (26) - (28) (Wang, Smarandache, Zhang \& Sunderraman, 2010):

$$
T\left(B_{3}\right)(x)=\max \left(T\left(B_{1}\right)(x), T\left(B_{2}\right)(x)\right)
$$




$$
\begin{gathered}
I\left(B_{3}\right)(x)=\min \left(I\left(B_{1}\right)(x), I\left(B_{2}\right)(x)\right) \\
F\left(B_{3}\right)(x)=\min \left(F\left(B_{1}\right)(x), F\left(B_{2}\right)(x)\right) \text { for all } x \in U
\end{gathered}
$$

The intersection of two SVNS namely $B_{1}$ and $B_{2}$ is an SVNS $B_{3}$ denoted by $B_{3}=B_{1} \cap B_{2}$ and its truth, indeterminacy and falsity membership functions are shown as Eqs. (29) - (31) (Liu \& Wang, 2014):

$$
\begin{gathered}
T\left(B_{3}\right)(x)=\min \left(T\left(B_{1}\right)(x), T\left(B_{2}\right)(x)\right) \\
I\left(B_{3}\right)(x)=\max \left(I\left(B_{1}\right)(x), I\left(B_{2}\right)(x)\right) \\
F\left(B_{3}\right)(x)=\max \left(F\left(B_{1}\right)(x), F\left(B_{2}\right)(x)\right) \text { for all } x \in U
\end{gathered}
$$

\subsection{Single-Valued Neutrosophic Sets (SVNS) Entropy Based Decision Making}

Nirmal and Bhatt (2016) proposed novelistic single-valued neutrosophic sets (SVNS) entropy based multi-attribute decision making (MADM) methodology composed of the following steps:

1. First step consisted of defining the type of decision-making problem (ranking, evaluation, sorting etc.)

2. After defining the problem type, alternatives regarding the criteria are identified. Values of the criteria may be qualitative or quantitative.

3. Decision matrix involving the criteria $K=\left\{K_{j}, j=1,2, \ldots, n\right\}$ and alternatives $L=\left\{L_{i}, i=1,2, \ldots, m\right\}$ regarding the decision-making problem is constructed.

4. Qualitative information is transformed to fuzzy numbers by means of matrix normalization techniques shown in Table 8.

Table 8: Matrix Normalization Techniques

\begin{tabular}{|lll|}
\hline Normalization technique & Normalized beneficial value & Normalized non-beneficial value \\
\hline $\begin{array}{l}\text { Linear scale transformation max } \\
\text { method }\end{array}$ & $N_{i j}=\frac{x_{i j}}{x_{i \max }}$ & $N_{i j}=\frac{x_{i \min }}{x_{i j}}$ \\
\hline $\begin{array}{l}\text { Linear scale transformation max-min } \\
\text { method }\end{array}$ & $N_{i j}=\frac{x_{i j}-\min x_{i j}}{\max x_{i j}-\min x_{i j}}$ & $N_{i j}=\frac{\max x_{i j}-x_{i j}}{\max x_{i j}-\min x_{i j}}$ \\
\hline $\begin{array}{l}\text { Linear scale transformation sum } \\
\text { method }\end{array}$ & $N_{i j}=\frac{x_{i j}}{\sum_{i=1}^{m} x_{i}}$ & $N_{i j}=1-\frac{x_{i j}}{\sum_{i=1}^{m} x_{i}}$ \\
\hline $\begin{array}{l}\text { Vector normalization method } \\
\sqrt{\sum_{i=1}^{m} x_{i j}^{2}}\end{array}$ & $N_{i j}=\frac{x_{i j}}{\sqrt{\sum_{i j} x_{i j}^{2}}}$ \\
\hline
\end{tabular}

5. Elements of input matrix in the classic or fuzzy set are converted to single-valued neutrosophic sets by means of conversion rule for beneficial and non-beneficial criteria as explained below:

a) For beneficial criteria: Positive ideal solution (PIS) is constructed as $<T_{\max }^{*}(x), I_{\text {min }}^{*}(x), F_{\min }^{*}(x)>$. Normalized input matrix beneficial criteria are created for the degree of truthness $T_{L}(x)$, the degree of indeterminacy and degree of falsehood are considered as $I_{L}(x)=F_{L}(x)=1-T_{L}(x)$ respectively.

b) For non-beneficial criteria: Negative ideal solution (NIS) is constructed as $<T_{\min }^{*}(x), I_{\max }^{*}(x), F_{\max }^{*}(x)>$. Normalized input matrix non-beneficial criteria are created for the degree of indeterminacy and falsehood as $I_{L}(x)=F_{L}(x)$, the degree of truthness is considered as $T_{L}(x)=1-I_{L}(x)=1-F_{L}(x)$. 
c) Entropy value for the jth attribute is calculated according to Eq.(32) as shown below:

$$
\left.\mathrm{E}_{\mathrm{j}}=1-\frac{1}{\mathrm{~m}}\left[\sum_{\mathrm{i}=1}^{\mathrm{m}}\left(\mathrm{T}_{\mathrm{ij}}\left(\mathrm{x}_{\mathrm{i}}\right)+\mathrm{F}_{\mathrm{ij}}\left(\mathrm{x}_{\mathrm{i}}\right)\right) 2\left(\mathrm{I}_{\mathrm{ij}}\left(\mathrm{x}_{\mathrm{i}}\right)\right)-1\right]\right]
$$

6. Entropy weight for the jth attribute is calculated according to the method proposed by Wang and Zhang (2009) as in Eq. (33):

$$
W_{j}=\frac{1-E_{j}}{\sum_{j=1}^{n}\left(1-E_{j}\right)}
$$

Weight vector $W=\left(w_{1}, w_{2}, w_{3}, \ldots, w_{n}\right)^{T}$ of attributes, $K=\left\{K_{j}, j=1,2, \ldots, n\right\}$ with $W_{j} \geq 0$ and $\sum_{j=1}^{n} W_{j}=1$

7. Value of each alternative is calculated as in Eq. (34):

$$
L_{w}=\sum_{j=1}^{n} W_{j} *\left(\left(T_{i j}(x) * T_{i j}^{*}(x)\right)+\left(I_{i j}(x) * I_{i j}^{*}(x)\right)+\left(F_{i j}(x) * F_{i j}^{*}(x)\right)\right)
$$

Where, for beneficial attribute $\mathrm{PIS}=<T_{\max }^{*}(x), I_{\min }^{*}(x), F_{\min }^{*}(x)>=<1,0,0>$, and for non-beneficial attribute NIS $=<$ $T_{\min }^{*}(x), I_{\max }^{*}(x), F_{\max }^{*}(x)>=<0,1,1>$.

8. Each alternative is ranked according to the descending order of $L_{w}$.

\section{FINDINGS AND DISCUSSIONS}

As a result, 35 complete surveys were analyzed by using Excel 2013 Software. Firstly, the 11-point scale suggested by Chen and Hwang (1992) was used to convert the linguistic terms of 35 experts into crisp values. The geometric means of mobile banking criteria were computed to obtain crisp values of decision matrix in terms of each alternative. Decision matrix for

\begin{tabular}{|c|c|c|c|c|c|c|c|c|c|c|c|c|c|c|c|c|}
\hline & C1 & C2 & C3 & C4 & C5 & C6 & $\mathrm{C7}$ & C8 & C9 & C10 & C11 & $\mathrm{C} 12$ & $\mathrm{C} 13$ & C14 & C15 & C16 \\
\hline A1 & 0.704 & 0.731 & 0.7 & 0.733 & 0.685 & 0.682 & 0.633 & 0.642 & 0.732 & 0.651 & 0.746 & 0.545 & 0.624 & 0.733 & 0.693 & 0.683 \\
\hline A2 & 0.648 & 0.616 & 0.647 & 0.67 & 0.685 & 0.658 & 0.641 & 0.637 & 0.742 & 0.669 & 0.682 & 0.639 & 0.626 & 0.65 & 0.659 & 0.665 \\
\hline A3 & 0.687 & 0.618 & 0.639 & 0.713 & 0.698 & 0.65 & 0.651 & 0.662 & 0.753 & 0.672 & 0.662 & 0.599 & 0.638 & 0.697 & 0.675 & 0.656 \\
\hline A4 & 0.703 & 0.684 & 0.694 & 0.721 & 0.705 & 0.672 & 0.68 & 0.705 & 0.75 & 0.692 & 0.7 & 0.66 & 0.669 & 0.667 & 0.669 & 0.665 \\
\hline A5 & 0.658 & 0.618 & 0.647 & 0.694 & 0.623 & 0.695 & 0.614 & 0.658 & 0.677 & 0.649 & 0.631 & 0.626 & 0.655 & 0.661 & 0.636 & 0.646 \\
\hline A6 & 0.705 & 0.722 & 0.674 & 0.726 & 0.702 & 0.701 & 0.66 & 0.737 & 0.727 & 0.694 & 0.719 & 0.624 & 0.712 & 0.674 & 0.703 & 0.706 \\
\hline A7 & 0.473 & 0.52 & 0.515 & 0.664 & 0.6 & 0.622 & 0.629 & 0.626 & 0.663 & 0.623 & 0.598 & 0.505 & 0.584 & 0.577 & 0.615 & 0.572 \\
\hline A8 & 0.623 & 0.613 & 0.627 & 0.628 & 0.534 & 0.668 & 0.539 & 0.649 & 0.621 & 0.531 & 0.525 & 0.575 & 0.597 & 0.585 & 0.631 & 0.597 \\
\hline A9 & 0.582 & 0.593 & 0.526 & 0.601 & 0.517 & 0.607 & 0.575 & 0.575 & 0.601 & 0.592 & 0.608 & 0.509 & 0.52 & 0.595 & 0.644 & 0.561 \\
\hline A10 & 0.547 & 0.579 & 0.612 & 0.666 & 0.562 & 0.644 & 0.496 & 0.56 & 0.555 & 0.485 & 0.471 & 0.562 & 0.581 & 0.605 & 0.617 & 0.612 \\
\hline A11 & 0.546 & 0.521 & 0.58 & 0.625 & 0.536 & 0.564 & 0.55 & 0.611 & 0.659 & 0.604 & 0.592 & 0.583 & 0.582 & 0.609 & 0.601 & 0.553 \\
\hline
\end{tabular}
crisp data is shown in Table 9.

Table 9: Decision Matrix for Crisp Data 


\begin{tabular}{|lllllllllllllllllll}
\hline A12 & 0.625 & 0.565 & 0.567 & 0.619 & 0.514 & 0.618 & 0.542 & 0.658 & 0.677 & 0.557 & 0.617 & 0.588 & 0.621 & 0.666 & 0.661 & 0.655 & \\
\hline A13 & 0.5 & 0.473 & 0.519 & 0.592 & 0.548 & 0.626 & 0.635 & 0.659 & 0.576 & 0.552 & 0.579 & 0.587 & 0.612 & 0.681 & 0.692 & 0.671 \\
\hline
\end{tabular}

After constructing the decision matrix, vector normalization method was used to obtain the normalized decision matrix. Then the normalized decision matrix was transformed into SVNS decision matrix consisting of the degree of truthness $T_{L}(x)$, indeterminacy $I_{L}(x)$, and falsehood $F_{L}(x)$ by means of conversion rule for beneficial and non-beneficial criteria and can be seen in Table 10.

Table 10: SVNS Decision Matrix

\begin{tabular}{|c|c|c|c|c|c|c|c|c|c|c|c|c|c|c|c|c|}
\hline & C1 & $\mathrm{C} 2$ & C3 & C4 & C5 & C6 & C7 & C8 & C9 & C10 & C11 & C12 & C13 & C14 & C15 & C16 \\
\hline A1 & $\begin{array}{l}(0.315 \\
, 0.684, \\
0.684)\end{array}$ & $\begin{array}{l}(0.331 \\
, 0.668, \\
0.668)\end{array}$ & $\begin{array}{l}(0.315 \\
, 0.684, \\
0.684)\end{array}$ & $\begin{array}{l}(0.304 \\
, 0.695, \\
0.695)\end{array}$ & $\begin{array}{l}(0.309 \\
, 0.690 \\
0.690)\end{array}$ & $\begin{array}{l}(0.292 \\
, 0.707 \\
0.707)\end{array}$ & $\begin{array}{l}(0.289 \\
, 0.710 \\
0.710)\end{array}$ & $\begin{array}{l}(0.275 \\
, 0.724, \\
0.724)\end{array}$ & $\begin{array}{l}(0.300 \\
, 0.699 \\
0.699)\end{array}$ & $\begin{array}{l}(0.292 \\
, 0.707 \\
0.707)\end{array}$ & $\begin{array}{l}(0.328 \\
, 0.671, \\
0.671)\end{array}$ & $\begin{array}{l}(0.257 \\
, 0.742 \\
0.742)\end{array}$ & $\begin{array}{l}(0.279 \\
, 0.720 \\
0.720)\end{array}$ & $\begin{array}{l}(0.313 \\
, 0.686, \\
0.686)\end{array}$ & $\begin{array}{l}(0.293 \\
, 0.706 \\
0.706)\end{array}$ & $\begin{array}{l}(0.297 \\
, 0.702, \\
0.702)\end{array}$ \\
\hline A2 & $\begin{array}{l}(0.290 \\
, 0.709 \\
0.709)\end{array}$ & $\begin{array}{l}(0.279 \\
, 0.720 \\
0.720)\end{array}$ & $\begin{array}{l}(0.291 \\
, 0.708, \\
0.708)\end{array}$ & $\begin{array}{l}(0.278 \\
, 0.721, \\
0.721)\end{array}$ & $\begin{array}{l}(0.309 \\
, 0.690, \\
0.690)\end{array}$ & $\begin{array}{l}(0.281 \\
, 0.718, \\
0.718)\end{array}$ & $\begin{array}{l}(0.293 \\
, 0.706, \\
0.706)\end{array}$ & $\begin{array}{l}(0.273 \\
, 0.726, \\
0.726)\end{array}$ & $\begin{array}{l}(0.304 \\
, 0.695 \\
0.695)\end{array}$ & $\begin{array}{l}(0.300 \\
, 0.699 \\
0.699)\end{array}$ & $\begin{array}{l}(0.300 \\
, 0.699, \\
0.699)\end{array}$ & $\begin{array}{l}(0.301 \\
, 0.698, \\
0.698)\end{array}$ & $\begin{array}{l}(0.280 \\
, 0.719, \\
0.719)\end{array}$ & $\begin{array}{l}(0.278 \\
, 0.721, \\
0.721)\end{array}$ & $\begin{array}{l}(0.279 \\
, 0.720, \\
0.720)\end{array}$ & $\begin{array}{l}(0.290 \\
, 0.709, \\
0.709)\end{array}$ \\
\hline A3 & $\begin{array}{l}(0.307 \\
0.692, \\
0.692)\end{array}$ & $\begin{array}{l}(0.279 \\
, 0.720 \\
0.720)\end{array}$ & $\begin{array}{l}(0.288 \\
, 0.711 \\
0.711)\end{array}$ & $\begin{array}{l}(0.296 \\
, 0.703, \\
0.703)\end{array}$ & $\begin{array}{l}(0.315 \\
, 0.684, \\
0.684)\end{array}$ & $\begin{array}{l}(0.278 \\
, 0.721, \\
0.721)\end{array}$ & $\begin{array}{l}(0.297 \\
, 0.702, \\
0.702)\end{array}$ & $\begin{array}{l}(0.284 \\
, 0.715, \\
0.715)\end{array}$ & $\begin{array}{l}(0.309 \\
, 0.690 \\
0.690)\end{array}$ & $\begin{array}{l}(0.302 \\
, 0.697 \\
0.697)\end{array}$ & $\begin{array}{l}(0.291 \\
, 0.708 \\
0.708)\end{array}$ & $\begin{array}{l}(0.283 \\
, 0.716 \\
0.716)\end{array}$ & $\begin{array}{l}(0.285 \\
, 0.714, \\
0.714)\end{array}$ & $\begin{array}{l}(0.298 \\
, 0.701, \\
0.701)\end{array}$ & $\begin{array}{l}(0.286 \\
, 0.713 \\
0.713)\end{array}$ & $\begin{array}{l}(0.286 \\
, 0.713, \\
0.713)\end{array}$ \\
\hline A4 & $\begin{array}{l}(0.310 \\
, 0.689, \\
0.689)\end{array}$ & $\begin{array}{l}(0.326 \\
, 0.673, \\
0.673)\end{array}$ & $\begin{array}{l}(0.317 \\
, 0.682, \\
0.682)\end{array}$ & $\begin{array}{l}(0.299 \\
, 0.700, \\
0.700)\end{array}$ & $\begin{array}{l}(0.318 \\
, 0.681, \\
0.681)\end{array}$ & $\begin{array}{l}(0.287 \\
, 0.712 \\
0.712)\end{array}$ & $\begin{array}{l}(0.311 \\
, 0.688, \\
0.688)\end{array}$ & $\begin{array}{l}(0.302 \\
, 0.697 \\
0.697)\end{array}$ & $\begin{array}{l}(0.308 \\
, 0.691, \\
0.691)\end{array}$ & $\begin{array}{l}(0.311 \\
, 0.688, \\
0.688)\end{array}$ & $\begin{array}{l}(0.308 \\
, 0.691, \\
0.691)\end{array}$ & $\begin{array}{l}(0.312 \\
, 0.687 \\
0.687)\end{array}$ & $\begin{array}{l}(0.299 \\
, 0.700 \\
0.700)\end{array}$ & $\begin{array}{l}(0.285 \\
, 0.714, \\
0.714)\end{array}$ & $\begin{array}{l}(0.283 \\
, 0.716 \\
0.716)\end{array}$ & $\begin{array}{l}(0.289 \\
, 0.710, \\
0.710)\end{array}$ \\
\hline A5 & $\begin{array}{l}(0.294 \\
, 0.705, \\
0.705)\end{array}$ & $\begin{array}{l}(0.279 \\
, 0.720 \\
0.720)\end{array}$ & $\begin{array}{l}(0.291 \\
, 0.708 \\
0.708)\end{array}$ & $\begin{array}{l}(0.288 \\
, 0.711, \\
0.711)\end{array}$ & $\begin{array}{l}(0.281 \\
, 0.718, \\
0.718)\end{array}$ & $\begin{array}{l}(0.297 \\
, 0.702 \\
0.702)\end{array}$ & $\begin{array}{l}(0.281 \\
, 0.718 \\
0.718)\end{array}$ & $\begin{array}{l}(0.282 \\
, 0.717 \\
0.717)\end{array}$ & $\begin{array}{l}(0.278 \\
, 0.721 \\
0.721)\end{array}$ & $\begin{array}{l}(0.292 \\
, 0.707 \\
0.707)\end{array}$ & $\begin{array}{l}(0.278 \\
, 0.721, \\
0.721)\end{array}$ & $\begin{array}{l}(0.296 \\
0.703, \\
0.703)\end{array}$ & $\begin{array}{l}(0.293 \\
, 0.706 \\
0.706)\end{array}$ & $\begin{array}{l}(0.282 \\
, 0.717 \\
0.717)\end{array}$ & $\begin{array}{l}(0.269 \\
, 0.730 \\
0.730)\end{array}$ & $\begin{array}{l}(0.281 \\
, 0.718, \\
0.718)\end{array}$ \\
\hline A6 & $\begin{array}{l}(0.315 \\
0.684, \\
0.684)\end{array}$ & $\begin{array}{l}(0.327 \\
, 0.672, \\
0.672)\end{array}$ & $\begin{array}{l}(0.303 \\
, 0.696 \\
0.696)\end{array}$ & $\begin{array}{l}(0.301 \\
, 0.698, \\
0.698)\end{array}$ & $\begin{array}{l}(0.317 \\
, 0.682 \\
0.682)\end{array}$ & $\begin{array}{l}(0.300 \\
, 0.699, \\
0.699)\end{array}$ & $\begin{array}{l}(0.302 \\
, 0.697 \\
0.697)\end{array}$ & $\begin{array}{l}(0.316 \\
, 0.683, \\
0.683)\end{array}$ & $\begin{array}{l}(0.298 \\
, 0.701 \\
0.701)\end{array}$ & $\begin{array}{l}(0.312 \\
0.687 \\
0.687)\end{array}$ & $\begin{array}{l}(0.316 \\
, 0.683, \\
0.683)\end{array}$ & $\begin{array}{l}(0.295 \\
, 0.704, \\
0.704)\end{array}$ & $\begin{array}{l}(0.319 \\
, 0.680 \\
0.680)\end{array}$ & $\begin{array}{l}(0.288 \\
, 0.711, \\
0.711)\end{array}$ & $\begin{array}{l}(0.298 \\
, 0.701 \\
0.701)\end{array}$ & $\begin{array}{l}(0.308 \\
, 0.691, \\
0.691)\end{array}$ \\
\hline A7 & $\begin{array}{l}(0.211 \\
, 0.788, \\
0.788)\end{array}$ & $\begin{array}{l}(0.235 \\
, 0.764, \\
0.764)\end{array}$ & $\begin{array}{l}(0.232 \\
, 0.767 \\
0.767)\end{array}$ & $\begin{array}{l}(0.276 \\
, 0.723, \\
0.723)\end{array}$ & $\begin{array}{l}(0.271 \\
, 0.728 \\
0.728)\end{array}$ & $\begin{array}{l}(0.266 \\
, 0.733, \\
0.733)\end{array}$ & $\begin{array}{l}(0.287 \\
, 0.712, \\
0.712)\end{array}$ & $\begin{array}{l}(0.268 \\
, 0.731, \\
0.731)\end{array}$ & $\begin{array}{l}(0.272 \\
, 0.727 \\
0.727)\end{array}$ & $\begin{array}{l}(0.280 \\
, 0.719 \\
0.719)\end{array}$ & $\begin{array}{l}(0.263 \\
, 0.736 \\
0.736)\end{array}$ & $\begin{array}{l}(0.238 \\
, 0.761, \\
0.761)\end{array}$ & $\begin{array}{l}(0.261 \\
, 0.738, \\
0.738)\end{array}$ & $\begin{array}{l}(0.247 \\
, 0.752, \\
0.752)\end{array}$ & $\begin{array}{l}(0.260 \\
, 0.739, \\
0.739)\end{array}$ & $\begin{array}{l}(0.249 \\
, 0.750, \\
0.750)\end{array}$ \\
\hline A8 & $\begin{array}{l}(0.278 \\
, 0.721, \\
0.721)\end{array}$ & $\begin{array}{l}(0.278 \\
, 0.721, \\
0.721)\end{array}$ & $\begin{array}{l}(0.282 \\
, 0.717 \\
0.717)\end{array}$ & $\begin{array}{l}(0.261 \\
, 0.738, \\
0.738)\end{array}$ & $\begin{array}{l}(0.241 \\
, 0.758, \\
0.758)\end{array}$ & $\begin{array}{l}(0.285 \\
, 0.714 \\
0.714)\end{array}$ & $\begin{array}{l}(0.246 \\
, 0.753, \\
0.753)\end{array}$ & $\begin{array}{l}(0.278 \\
, 0.721, \\
0.721)\end{array}$ & $\begin{array}{l}(0.255 \\
, 0.744 \\
0.744)\end{array}$ & $\begin{array}{l}(0.238 \\
, 0.761, \\
0.761)\end{array}$ & $\begin{array}{l}(0.231 \\
, 0.768, \\
0.768)\end{array}$ & $\begin{array}{l}(0.271 \\
, 0.728 \\
0.728)\end{array}$ & $\begin{array}{l}(0.267 \\
, 0.732, \\
0.732)\end{array}$ & $\begin{array}{l}(0.250 \\
, 0.749 \\
0.749)\end{array}$ & $\begin{array}{l}(0.267 \\
, 0.732, \\
0.732)\end{array}$ & $\begin{array}{l}(0.260 \\
, 0.739, \\
0.739)\end{array}$ \\
\hline A9 & $\begin{array}{l}(0.260 \\
, 0.739, \\
0.739)\end{array}$ & $\begin{array}{l}(0.268 \\
, 0.731, \\
0.731)\end{array}$ & $\begin{array}{l}(0.237 \\
, 0.762, \\
0.762)\end{array}$ & $\begin{array}{l}(0.249 \\
, 0.750 \\
0.750)\end{array}$ & $\begin{array}{l}(0.234 \\
, 0.765, \\
0.765)\end{array}$ & $\begin{array}{l}(0.259 \\
, 0.740 \\
0.740)\end{array}$ & $\begin{array}{l}(0.263 \\
, 0.736 \\
0.736)\end{array}$ & $\begin{array}{l}(0.246 \\
, 0.753, \\
0.753)\end{array}$ & $\begin{array}{l}(0.247 \\
, 0.752 \\
0.752)\end{array}$ & $\begin{array}{l}(0.266 \\
, 0.733, \\
0.733)\end{array}$ & $\begin{array}{l}(0.267 \\
, 0.732, \\
0.732)\end{array}$ & $\begin{array}{l}(0.240 \\
, 0.759 \\
0.759)\end{array}$ & $\begin{array}{l}(0.233 \\
, 0.766 \\
0.766)\end{array}$ & $\begin{array}{l}(0.254 \\
, 0.745, \\
0.745)\end{array}$ & $\begin{array}{l}(0.272 \\
, 0.727 \\
0.727)\end{array}$ & $\begin{array}{l}(0.244 \\
, 0.755, \\
0.755)\end{array}$ \\
\hline $\begin{array}{l}\text { A1 } \\
\mathbf{0}\end{array}$ & $\begin{array}{l}(0.244 \\
, 0.755, \\
0.755)\end{array}$ & $\begin{array}{l}(0.262 \\
, 0.737 \\
0.737)\end{array}$ & $\begin{array}{l}(0.275 \\
, 0.724, \\
0.724)\end{array}$ & $\begin{array}{l}(0.276 \\
, 0.723, \\
0.723)\end{array}$ & $\begin{array}{l}(0.254 \\
, 0.745, \\
0.745)\end{array}$ & $\begin{array}{l}(0.275 \\
, 0.724, \\
0.724)\end{array}$ & $\begin{array}{l}(0.226 \\
, 0.773, \\
0.773)\end{array}$ & $\begin{array}{l}(0.240 \\
, 0.759, \\
0.759)\end{array}$ & $\begin{array}{l}(0.228 \\
, 0.771 \\
0.771)\end{array}$ & $\begin{array}{l}(0.218 \\
, 0.781, \\
0.781)\end{array}$ & $\begin{array}{l}(0.207 \\
, 0.792, \\
0.792)\end{array}$ & $\begin{array}{l}(0.265 \\
, 0.734, \\
0.734)\end{array}$ & $\begin{array}{l}(0.260 \\
, 0.739 \\
0.739)\end{array}$ & $\begin{array}{l}(0.258 \\
, 0.741, \\
0.741)\end{array}$ & $\begin{array}{l}(0.261 \\
, 0.738 \\
0.738)\end{array}$ & $\begin{array}{l}(0.267 \\
, 0.732, \\
0.732)\end{array}$ \\
\hline $\begin{array}{l}\text { A1 } \\
1\end{array}$ & $\begin{array}{l}(0.244 \\
, 0.755, \\
0.755)\end{array}$ & $\begin{array}{l}(0.236 \\
, 0.763, \\
0.763)\end{array}$ & $\begin{array}{l}(0.261 \\
, 0.738 \\
0.738)\end{array}$ & $\begin{array}{l}(0.259 \\
, 0.740 \\
0.740)\end{array}$ & $\begin{array}{l}(0.242 \\
, 0.757 \\
0.757)\end{array}$ & $\begin{array}{l}(0.241 \\
, 0.758 \\
0.758)\end{array}$ & $\begin{array}{l}(0.251 \\
, 0.748, \\
0.748)\end{array}$ & $\begin{array}{l}(0.262 \\
, 0.737 \\
0.737)\end{array}$ & $\begin{array}{l}(0.270 \\
, 0.729 \\
0.729)\end{array}$ & $\begin{array}{l}(0.272 \\
, 0.727 \\
0.727)\end{array}$ & $\begin{array}{l}(0.260 \\
, 0.739, \\
0.739)\end{array}$ & $\begin{array}{l}(0.275 \\
, 0.724 \\
0.724)\end{array}$ & $\begin{array}{l}(0.260 \\
, 0.739 \\
0.739)\end{array}$ & $\begin{array}{l}(0.260 \\
, 0.739 \\
0.739)\end{array}$ & $\begin{array}{l}(0.254 \\
, 0.745, \\
0.745)\end{array}$ & $\begin{array}{l}(0.241 \\
, 0.758, \\
0.758)\end{array}$ \\
\hline $\begin{array}{l}\text { A1 } \\
2\end{array}$ & $\begin{array}{l}(0.279 \\
, 0.720 \\
0.720)\end{array}$ & $\begin{array}{l}(0.256 \\
, 0.743, \\
0.743)\end{array}$ & $\begin{array}{l}(0.255 \\
, 0.744, \\
0.744)\end{array}$ & $\begin{array}{l}(0.257 \\
, 0.742, \\
0.742)\end{array}$ & $\begin{array}{l}(0.232 \\
, 0.767 \\
0.767)\end{array}$ & $\begin{array}{l}(0.264 \\
, 0.735, \\
0.735)\end{array}$ & $\begin{array}{l}(0.248 \\
, 0.751, \\
0.751)\end{array}$ & $\begin{array}{l}(0.282 \\
, 0.717 \\
0.717)\end{array}$ & $\begin{array}{l}(0.278 \\
, 0.721 \\
0.721)\end{array}$ & $\begin{array}{l}(0.250 \\
, 0.749 \\
0.749)\end{array}$ & $\begin{array}{l}(0.271 \\
, 0.728, \\
0.728)\end{array}$ & $\begin{array}{l}(0.278 \\
, 0.721 \\
0.721)\end{array}$ & $\begin{array}{l}(0.278 \\
, 0.721 \\
0.721)\end{array}$ & $\begin{array}{l}(0.285 \\
, 0.714, \\
0.714)\end{array}$ & $\begin{array}{l}(0.280 \\
, 0.719 \\
0.719)\end{array}$ & $\begin{array}{l}(0.285 \\
, 0.714, \\
0.714)\end{array}$ \\
\hline $\begin{array}{l}\text { A1 } \\
3\end{array}$ & $\begin{array}{l}(0.223 \\
, 0.776 \\
0.776)\end{array}$ & $\begin{array}{l}(0.214 \\
, 0.785, \\
0.785)\end{array}$ & $\begin{array}{l}(0.234 \\
, 0.765, \\
0.765)\end{array}$ & $\begin{array}{l}(0.246 \\
, 0.753 \\
0.753)\end{array}$ & $\begin{array}{l}(0.248 \\
, 0.751, \\
0.751)\end{array}$ & $\begin{array}{l}(0.268 \\
, 0.731, \\
0.731)\end{array}$ & $\begin{array}{l}(0.290 \\
, 0.709 \\
0.709)\end{array}$ & $\begin{array}{l}(0.282 \\
, 0.717 \\
0.717)\end{array}$ & $\begin{array}{l}(0.236 \\
, 0.763 \\
0.763)\end{array}$ & $\begin{array}{l}(0.248 \\
, 0.751, \\
0.751)\end{array}$ & $\begin{array}{l}(0.254 \\
, 0.745, \\
0.745)\end{array}$ & $\begin{array}{l}(0.277 \\
, 0.722, \\
0.722)\end{array}$ & $\begin{array}{l}(0.274 \\
, 0.725, \\
0.725)\end{array}$ & $\begin{array}{l}(0.291 \\
, 0.708 \\
0.708)\end{array}$ & $\begin{array}{l}(0.293 \\
, 0.706 \\
0.706)\end{array}$ & $\begin{array}{l}(0.292 \\
, 0.707, \\
0.707)\end{array}$ \\
\hline $\begin{array}{l}\text { Id } \\
\text { eal } \\
\text { Sol } \\
\text { uti } \\
\text { on } \\
\text { s }\end{array}$ & $\begin{array}{l}(0.315 \\
, 0.684, \\
0.684)\end{array}$ & $\begin{array}{l}(0.214 \\
, 0.785, \\
0.785)\end{array}$ & $\begin{array}{l}(0.317 \\
, 0.682, \\
0.682)\end{array}$ & $\begin{array}{l}(0.304 \\
, 0.695, \\
0.695)\end{array}$ & $\begin{array}{l}(0.318 \\
, 0.681, \\
0.681)\end{array}$ & $\begin{array}{l}(0.300 \\
, 0.699 \\
0.699)\end{array}$ & $\begin{array}{l}(0.311 \\
, 0.688, \\
0.688)\end{array}$ & $\begin{array}{l}(0.316 \\
, 0.683, \\
0.683)\end{array}$ & $\begin{array}{l}(0.309 \\
, 0.690 \\
0.690)\end{array}$ & $\begin{array}{l}(0.312 \\
, 0.687, \\
0.687)\end{array}$ & $\begin{array}{l}(0.328 \\
, 0.671, \\
0.671)\end{array}$ & $\begin{array}{l}(0.312 \\
, 0.687 \\
0.687)\end{array}$ & $\begin{array}{l}(0.319 \\
, 0.680, \\
0.680)\end{array}$ & $\begin{array}{l}(0.313 \\
, 0.686 \\
0.686)\end{array}$ & $\begin{array}{l}(0.298 \\
, 0.701, \\
0.701)\end{array}$ & $\begin{array}{l}(0.308 \\
, 0.691, \\
0.691)\end{array}$ \\
\hline
\end{tabular}


Afterwards, entropy values $\left(E_{j}\right)$ and weights $\left(W_{j}\right)$ for each criteria were calculated using Eqs.(32)-(33) as shown in Table 11.

Table 11: Entropy Values $\left(E_{j}\right)$ and Weights $\left(W_{j}\right)$ for Each Mobile Banking Quality Criteria

\begin{tabular}{|lcc|}
\hline Criteria & Entropy value $\left(\mathrm{E}_{\mathrm{j}}\right)$ & Entropy weight $\left(\mathrm{W}_{\mathrm{j}}\right)$ \\
\hline Accessibility & 0.550551 & 0.062750 \\
\hline Response time & 0.550274 & 0.062789 \\
\hline Mobility & 0.551767 & 0.062580 \\
\hline Security & 0.553303 & 0.062366 \\
\hline Accuracy & 0.550605 & 0.062743 \\
\hline Currency & 0.553783 & 0.062299 \\
\hline Relevance & 0.552461 & 0.062484 \\
\hline Completeness & 0.553337 & 0.062362 \\
\hline Reliability & 0.552126 & 0.062531 \\
\hline Responsiveness & 0.551724 & 0.062587 \\
\hline Trust & 0.550838 & 0.062711 \\
\hline Empathy & 0.553063 & 0.062400 \\
\hline Multimedia Capability & 0.553186 & 0.062383 \\
\hline Format & 0.553309 & 0.062366 \\
\hline Understandability & 0.554065 & 0.062260 \\
\hline Navigability & 0.553141 & 0.062389 \\
\hline
\end{tabular}

According to Table 11, entropy weights of the criteria are close to each other. Response time was, however, found to be the most significant criterion, followed by accessibility, accuracy and trust. On the other hand, understandability was determined to be the least important criterion. According to the results of entropy weights banks should give more importance to the accessibility, accuracy and trust in providing $\mathrm{m}$-banking services. Experts indicated the criticality of easy to access, providing accurate information and confidence of using mobile devices for conducting banking transactions than other m-banking quality factors in customers' viewpoint. Finally, value of each bank $\left(\mathrm{L}_{\mathrm{w}}\right)$ was computed by utilizing Eq. (34) and ranked according to descending order as shown in Table 12.

Table 12: Value of each bank $\left(\mathrm{L}_{\mathrm{w}}\right)$ and ranking

\begin{tabular}{|llc|}
\hline Bank & Value $\left(\mathrm{L}_{\mathrm{w}}\right)$ & Ranking \\
\hline Ziraat Bankasi (A1) & 1.062651 & 11 \\
\hline Halk Bankasi (A2) & 1.074574 & 9 \\
\hline Vakıflar Bankasi (A3) & 1.070677 & 10 \\
\hline Akbank (A4) & 1.057774 & 12 \\
\hline Garanti Bankasi (A5) & 1.078766 & 8 \\
\hline İs Bankasi (A6) & 1.054618 & 13 \\
\hline Yapi ve Kredi Bankasi (A7) & 1.109083 & 4 \\
\hline Finansbank (A8) & 1.103417 & 6 \\
\hline TEB (A9) & 1.113481 & 2 \\
\hline Denizbank (A10) & 1.115058 & 1 \\
\hline ING (A11) & 1.111032 & 3 \\
\hline Sekerbank (A12) & 1.098107 & 7 \\
\hline HSBC (A13) & 1.105814 & 5 \\
\hline
\end{tabular}

According to Table 12, Denizbank (A10) had the biggest $\mathrm{L}_{\mathrm{w}}$ value and ranked as the first followed by TEB (A9), ING (A11) and Yapi ve Kredi Bankasi (A7). On the other hand, is Bankasi (A6) had the lowest $\mathrm{L}_{\mathrm{w}}$ value and ranked as the last. Also, it was observed that while private banks ranked as the top five positions, state banks ranked as the last five one. That shows the success of private banks in mobile banking applications compared to public banks in Turkey. 


\section{CONCLUSION}

Mobile banking quality as newly developed concept has gained importance in past decades. So analyzing the $m$-banking quality, defined as customer decisions with respect to the quality of mobile content delivery in terms of $m$-banking, is crucial for banks providing m-banking services in terms of improving customer adoption rate. In this study, SVNS entropy based decision making is used to rank banks providing mobile banking applications in Turkey under incomplete, indeterminate and inconsistent information. An approximation approach proposed by Chen and Hwang is used to transform respondents' linguistic terms to crisp values. To the best of our knowledge, this is the first study in evaluating $\mathrm{m}$ banking quality factors of banks in Turkey from the neutrosophic set perspective. According to the results of entropy weights, response time was found to be the most significant criterion followed by accessibility, accuracy and trust. This indicates the importance of response time, accessibility, accuracy and trust for banks in implementing m-banking services. On the contrary, understandability was found to be the least important criterion according to the judgments of respondents. Banks can reconsider their m-banking services by taking experts' views into the account. Enabling easy to access, providing accurate information and confidence of using mobile devices for banking transactions can retain existing customers and increase their adoption in $\mathrm{m}$-banking. From the banks' perspective, Denizbank was ranked as the first in $\mathrm{m}$ banking applications followed by TEB and ING. On the other hand, Ziraat Bankası, Akbank and iş Bankası were considered as the three worst banks for implementing $\mathrm{m}$-banking services.

In future studies, other neutrosophic logic-based techniques and normalization methods (out of vector normalization) could be used to analyze this concept. Also, when converting experts' linguistic terms into crisp ones, other transformation methods could be used. SVNS based entropy technique could be applied to the banking industries of different countries regarding the $\mathrm{m}$-banking quality factors. Thus the practicability of study can be expanded. In addition, other $\mathrm{m}$-banking quality criteria can be added to enrich the context of study. Lastly, this methodology may also be applied to different sectors.

\section{REFERENCES}

Atanassov, K. (1986). Intuitionistic fuzzy sets. Fuzzy Sets \& Systems, 20, 87-96.

Biswas, P., Pramanik, S. \& Giri, B.C. (2016a). Some Distance Measures of Single Valued Neutrosophic Hesitant Fuzzy Sets and Their Applications to Multiple Attribute Decision Making, In New Trends in Neutrosophic Theory and Applications, F. Smarandache and S. Pramanik (Ed.), Pons Publishing House, Brussels, 27-34.

Biswas, P., Pramanik, S. \& Giri, B.C. (2016b). TOPSIS method for multi-attribute group decision making under single-valued neutrosophic environment. Neural Computing and Applications, 27(3), 727-737.

Chen, S.J. \& Hwang, C.L. (1992). Fuzzy multiple attribute decision-making methods and applications. Lecture Notes in Economics and Mathematical Systems. Berlin: Springer-Verlag.

Derbent, A. (2011). Mobil Yaşam ve Uygulamaları, (Ed. Gonca Telli Yamamoto), MMA Raporu, İstanbul.

Hussain, A.N., Mohamed, M., Abdel-Baset, M. \& Smarandache, F. (2017). Neutrosophic Linear Programming Problems, In Neutrosophic Operational Research, F. Smarandache, M. Abdel-Baset and Y.Q. Zhou (Ed.), Volume 1, Pons Publishing House, Brussels, 15-27.

Kim, G., Sin, B. \& Lee, H.G. (2009). Understanding dynamics between initial trust and usage intentions of mobile banking. Information Systems Journal, 19(3), 283-311.

Laforet, S. \& Li, X. (2005). Consumers' Attitudes Towards Online and Mobile Banking in China, International Journal of Bank Marketing, 23(5), 362-380.

Laukkanen, T.(2007). Internet vs Mobile Banking: Comparing Customer Value Perceptions, Business Process Management Journal, 13(6), 788-797.

Lin, H.F. (2013). Determining the relative importance of mobile banking quality factors. Computer Standards \& Interfaces, 35, 195-204.

Liu, P. \& Wang, Y. (2014). Multiple attribute decision-making method based on single-valued neutrosophic normalized weighted Bonferroni mean. Neural Computing and Applications, 25, 2001-2010.

Lu, Y., Zhang, L. \& Wang, B. (2009). A multidimensional and hierarchical model of mobile service quality. Electronic Commerce Research and Applications, 8(5), 228-240.

Mondal, K., Pramanik, S. \& Smarandache, F. (2016). Several Trigonometric Hamming Similarity Measures of Rough Neutrosophic Sets and their Applications in Decision Making, In New Trends in Neutrosophic Theory and Applications, F. Smarandache and S. Pramanik (Ed.), Pons Publishing House, Brussels, 93-103. 
Nirmal, N.P. \& Bhatt, M.G. (2016). Selection of Automated Guided Vehicle Using Single Valued Neutrosophic Entropy Based Novel MultiAttribute Decision Making, In New Trends in Neutrosophic Theory and Applications, F. Smarandache and S. Pramanik (Ed.), Pons Publishing House, Brussels, 105-114.

Padmanaban, K. \& Joseph, T. (2014). Factors influencing customers' adoption of mobile banking services: An exploratory study. International Journal of Research in Commerce \& Management, 5(12), 60-64.

Rao, R.V. (2007). Decision making in the manufacturing environment using graph theory and fuzzy multiple attribute decision making. London: Springer-Verlag.

Rao, R.V. \& Parnichkun, M. (2009). Flexible manufacturing system selection using a combinatorial mathematics-based decision-making method. International Journal of Production Research, 47(24), 6981-6998.

Smarandache, F. (1998). A unifying field in logics, neutrosophy: neutrosophic probability, set and logic. American Research Press, Rehoboth.

Şahin, R. \& Yiğider, M. (20). A Multi-criteria neutrosophic group decision-making method based TOPSIS for supplier selection, arXiv preprint arXiv:1412.5077.

Tan, F.B. \& Chou, J.P.C. (2008). The relationship between mobile service quality, perceived technology compatibility, and users' perceived playfulness in the context of mobile information and entertainment services. International Journal of Human-Computer Interaction, 24(7), 649-671.

Wang, H., Smarandache, F., Zhang, Y.Q. \& Sunderraman, R. (2010). Single-valued neutrosophic sets. Multispace and Multistructure, 4, 410413.

Wang, J. \& Zhang, Z. (2009). Multi-criteria decision-making method with incomplete certain information based on intuitionistic fuzzy number. Control and Decision, 24(2), 226-230.

Yu, T.K. \& Fang, K. (2009). Measuring the post-adoption customer perceptions of mobile banking services. CyberPsychology \& Behavior, 12(1), 33-35.

Zadeh, L.A. (1965). Fuzzy Sets. Information and Control, 8, 338-353.

Zhuo, Q.Y. \& Li, Y. (2010). Chinese mobile banking service evaluation based on AHP method. International Conference on E-Product, EService and E-Entertainment (ICEEE), 1-5.

Zhou, T. (2012). Understanding users' initial trust in mobile banking: An elaboration likelihood perspective. Computers in Human Behavior, 28(4), 1518-1525.

https://www.tbb.org.tr/en/banks-and-banking-sector-information/statistical-reports/20 (Accessed: 04.10.2017)

https://www.tbb.org.tr/tr/internet and mobile banking statistics/3635 (Accessed: 05.10.2017) 